Original Contribution

\title{
INFLUENCE OF DIETARY CINNAMOMUM VERUM EXTRACT ON THE GROWTH AND ECONOMIC EFFICACY OF COMMON CARP /CYPRINUS CARPIO L. /, REARED IN A RECIRCULATION SYSTEM
}

\author{
S. Stoyanova*, G. Zhelyazkov, I. Sirakov, K. Velichkova, Y. Staykov \\ Department of Biology and Aquaculture, Faculty of Agriculture, Trakia University, Stara Zagora, \\ Bulgaria
}

\begin{abstract}
The use of herbs as feed additives for fish showed a stimulating effect on growth, feed assimilation and increase its digestibility. The aim of research was to assess the outcome of feeding dietary cinnamon extract on the survival rate, growth performance, feed conversion and production efficiency of common carp (Cyprinus carpio L.), farmed in recirculation system. Thirty-two carps were distributed in two experimental variants, with two replicates of eight fish per group each. The average weight of the carps from the control and experimental group (CG) and EG) was $866.56 \pm 113.99 \mathrm{~g}$ and $869.38 \pm 96.88 \mathrm{~g}$, respectively $(\mathrm{p}>0.05)$. The average individual carp grown EG was by $18.98 \%$ higher vs CG fish, with no significant differences between groups ( $p>0.05$ ). The economic efficiency of feed with extract of cinnamon in the experimental group had better coefficient of economic efficiency 2.71 , which is lower by $4.61 \%$ compared to the coefficient of the controls
\end{abstract}

Key words: common carp, Cinnamomum verum, feed conversion ratio, survival rate, economic efficiency

\section{INTRODUCTION}

In recent years, feed fish to improve their capacity to put different types of supplements to increase growth, health, immunity and fish productivity (1-3). Immunostimulators are included as a requirement for organic aquaculture and their use in the feed industry is a common practice (4-6). Positive results have been found in tracking the stimulation of the growth of the fish and a high feed conversion by adding various herbs- garlic, onion, cumin, basil, anise, dill, fenugreek, thyme and paprika (7-20). Cinnamon /Cinnamomum zeylanicum / is known, as a seasoning of food for humans. It has a anti-emetic, anti-diarrheal and digestive stimulation properties, contains numerous bioactive molecules including polyphenol essential oils, tannins, saponins, flavonoids and carbohydrates (20-23). Bioactivity of cinnamon is associated with biological functions, antioxidants and antimicrobial

\footnotetext{
*Correspondence to: Stefka Stoyanova, Department of Biology and Aquaculture, Faculty of Agriculture, Trakia University, Students campus, 6014 Stara Zagora, Bulgaria, +359882024050; st_stoyanova@mail.bg
}

properties $(24,25)$. Cinnamon essential oil, tannins, calcium oxalate, resin, etc. $(26,27)$. The benefits of cinnamon in men comprised lower rate of gastric emptying and reduced blood sugar (28). The extract of cinnamon is able to reduce total cholesterol, LDL cholesterol, to raise HDL cholesterol and reduce triglyceride, in blood and fat accumulation in the rabbit liver (27). Therefore, the use of cinnamon as a natural food supplement has a beneficial effect on growth, food utilisation and resistance to A. hydrophila infection $(28,29)$.

The study was designed to determine the outcome of giving fish dietary cinnamon extract on the survival rate, growth, feed conversion ratio, economic efficiency of common carp (Cyprinus carpio L.), in a recirculation system.

\section{MATERIAL AND METHODS}

Thirty-two common carps were distributed to 2 variants, each with 2 replications with 8 fish. The mean initial weight of carps from the control (CG) and experimental groups (EG) was $866.56 \pm 113.99 \mathrm{~g}$ and $868.50 \pm 111.18 \mathrm{~g}$, 
respectively. Fish were grown in concrete tanks (effective volume $0.8 \mathrm{~m}^{3}$, parts of a recirculation system. They received pelleted diet with $25 \%$ crude protein, produced by "Top Mix" co., pellet $6 \mathrm{~mm}$. The EG fish were supplemented with $1 \%$ cinnamon extract powder by oiling pellets with $5 \mathrm{ml} / 100 \mathrm{~g}$ sunflower oil. Control groups were fed the same quantity of sunflower oil fodder. Nutritional content of pelleted feed of the groups was the following:

CG- Crude protein -25\%; Crude lipids- 3,10\%; Crude fiber -6\%; Crude ash -8\%;P-1,04; ME$11,10, \mathrm{MJ} / \mathrm{kg} ;$ Vitamin A- $4800 \mathrm{IU} / \mathrm{kg}$; Vitamin D -900 IU/kg;

EG. Crude protein - 25\%; Crude lipids $-3,10$ $\%$; Crude fiber- $6,00 \%$; Crude ash $-8,00 \%$; P $1,04 \%$; cinnamon extract $-1 \%$; ME- 11,10 $\mathrm{MJ} / \mathrm{kg}$;Vitamin A- $4800 \mathrm{IU} / \mathrm{kg}$; Vitamin D $900 \mathrm{IU} / \mathrm{kg}$.

The daily ration of the 2 repeats of experimental groups was $1.8 \%$ of weight. The trial period was 45 days.

\section{Hydrochemical Analysis}

The parameters of the water in the recirculation system were analysed by methods adapted for fish farming:

-Dissolved oxygen, mg. $1^{-1}-$ MultiLine P4; -pH - MultiLine P4;

-Electrical conductivity, $\mu \mathrm{S} . \mathrm{cm}^{-1} \quad-$ MultiLine P4 (BDS EN 27888);

The water parameters were measured every day.

\section{Growth performance}

In order to assess dietary cinnamon effect on weight gain and feed conversion in common carps in the recirculation system, fish were weighed at baseline and at end of the experiment. The live weight $(\mathrm{g})$ was obtained by individual weighing of fish. By the trial the weight gain $(\mathrm{g})$, survival rate $(\%)$ and the feed conversion ratio were determined.

\section{Economic analysis}

The economic efficiency of cinnamon extract supplementation to the ration of carps (Cyprinus carpio L.), farmed in recirculation system was calculated from data for feed conversion ratio, weight gain and survival rate. Comparisons of traits were performed between the groups. The costs for extruded feed were determined. The price cost of $1 \mathrm{~kg}$ weight gain of carps cultivated in recirculation system was determined. The economic conversion ratio (ECR) was calculated (30):

$\mathrm{ECR}=$ Diet cost $\mathrm{x}$ FCR,

where,

ECR - economic conversion ratio;

cost of diet - leva;

FCR - feed conversion ratio.

Statistical analysis of data was done (STATISTICA 6.0, StatSoft Inc., 2002).

\section{RESULTS}

\section{Hydrochemical analysis}

During the trial the water parameters in the recirculation system were maintained within the optimal ranges for common carps (Table 1). Water temperature for the 2 groups was $24.00 \pm 1.48^{\circ} \mathrm{C}$, and dissolved oxygen content $6.63 \pm 0.32 \mathrm{mg} . \mathrm{l}^{-1}$. Water $\mathrm{pH}$ in the different tanks was $7.66 \pm 0.24$. Electric conductivity of water was on the average $675 \pm 25.00 \mu \mathrm{S}_{\mathrm{cm}} \mathrm{cm}^{-1}$.

Table 1. Water parameters in the recirculation system during the experiment with common carp

\begin{tabular}{|l|c|c|c|}
\hline Parameter & $\mathbf{n}$ & $\bar{x} \pm \mathrm{SD}$ & $\begin{array}{c}\text { Optimum values } \\
\text { (Regulation № 4/2000) }\end{array}$ \\
\hline Temperature, ${ }^{\circ} \mathrm{C}$ & 45 & $25.00 \pm 1.49$ & $22.0-26.0$ \\
\hline Dissolved oxygen, mg. ${ }^{-1}$ & 45 & $6.61 \pm 0.30$ & $>5$ \\
\hline $\mathrm{pH}$ & 45 & $7.63 \pm 0.21$ & $6.5-8.5$ \\
\hline Electric conductivity, $\mu \mathrm{S} . \mathrm{cm}^{-1}$ & 45 & $673.00 \pm 28.00$ & - \\
\hline
\end{tabular}

\section{Growth of the common carp}

The average baseline body weight of the common carp in the two repetitions of the experimental and the control groups was $866.56 \pm 113.99 \mathrm{~g}$ and $869.38 \pm 96.85 \mathrm{~g}$, respectively, but the differences were statistically insignificant $(\mathrm{P}>0.05)$ (Table 2). At the end of the research trial, there was a trend for a higher live weight in fish fed $1 \%$ cinnamon extract $-986.44 \pm 125.91 \mathrm{~g}$, compared to control fish with $964.94 \pm 92.04$ $\mathrm{g}$, although differences between the groups but 
were not statistically significant $(P>0.05)$

(Table 2). Survival of common carp for the time of the experiment is presented in the Table 2. In repetitions of the test group fed $1 \%$ cinnamon survival rate was $100 \%$. At the end an average weight gain of carps of the two repetitions of EG, fed with $1 \%$ extract of cinnamon was $117.06 \pm 28.85 \mathrm{~g}$, and in control fish it was $98.38 \pm 25.63(\mathrm{P}>0.05)$ (Table 2). By the end of the trial, FCR analysis showed that the carp nutrition coefficient of the test group (with addition of $1 \%$ cinnamon extract) was $3.09 \pm 0.90$ e.g. by $21.68 \%$ lower than control fish $(\mathrm{P}>0.05)$ (Table 3).

Table 2. Fish production parameters

\begin{tabular}{|l|l|l|l|}
\hline \multirow{2}{*}{ Parameter } & \multirow{2}{*}{$\mathbf{n}$} & \multirow{2}{*}{ CG } & \multirow{2}{*}{ EG } \\
\cline { 3 - 4 } & & $\bar{x}_{ \pm \mathrm{SD}}$ & $\bar{x}_{ \pm \mathrm{SD}}$ \\
\hline Initial body weight, g & 16 & $866.56 \pm 113.99$ & $869.38 \pm 96.88$ \\
\hline Final body weight, g & 16 & $964.94 \pm 92.04$ & $986.44 \pm 120.32$ \\
\hline Survival rate, \% & & 100 & 100 \\
\hline Average individual weight gain, g & 16 & $98.38 \pm 25.63$ & $117.06 \pm 28.85$ \\
\hline FCR & & 3.76 & 3.09 \\
\hline
\end{tabular}

\section{Economic analysis}

The price of the pellets was $750 \mathrm{BGN} /$ tonne, VAT excluded. To it, the costs for cinnamon extract should be added, so the feed of the experimental group was more expensive by 120 BGN per tonne, VAT excluded.
The economic conversion ratio of the $1 \%$ cinnamon extract group was 2.71 , by $4.6 \%$ lower than that of other group.

Table 3. Economic efficiency of common carp, grown in recirculation system.

\begin{tabular}{|l|c|c|}
\hline Parameter/Group & CG & EG \\
\hline Price, BGN/t (VAT excluded) & 750.00 & 870.00 \\
\hline ECR & 2.82 & 2.69 \\
\hline
\end{tabular}

\section{DISCUSSION}

The analysis of hydrochemical data obtained (temperature, dissolved oxygen, $\mathrm{pH}$ and electrical conductivity) indicates that they are in the optimal range for the growing of common carp. The addition of $1 \%$ cinnamon extract to pelleted carp feed in the recirculating system has no effect on the survival of the fish. The results coincided with data from the studies of (32). This is due to the maintenance of values of the hydrochemical parameters required for cultivation of the given species, with optimized stock density, daily ration, feeding.

The of the average weight gain analysis of fish from the two EG repeats fed $1 \%$ cinnamon extract showed that it was $117.06 \pm 28.85 \mathrm{~g}$ e.g. by $18.98 \%$ lower than control fish; the differences were statistically insignificant $(\mathrm{P})$ 0.05) (Table 3). At trial's end, feed conversion ratio in the group with $1 \%$ cinnamon extract was $3.09 \pm 0.90$ and it was by $21.68 \%$ lower vs controls ( $\mathrm{P}>0.05)$ (Table 3). The lower FCR and better use of the feed with cinnamon is also found in surveys for other fish species (29, 32). Others (31) have found in common carp with added cinnamon in the feed, lower growth in the experimental group but reported despite the better utilization of the feed in the same group is also contrasted with that obtained in the present study. At the end, a higher average weight gain trend was observed in fish receiving $1 \%$ cinnamon extract - $986.44 \pm$ $120.32 \mathrm{~g}$ compared to the control where it was $2.22 \%$ lower but the differences were not statistically significant $(\mathrm{P}>0.05)$ (Table 3).

According to the authors analyzed the developments in the positive effect on the growth of the fish with the addition of $1 \%$ of cinnamon powder, or $1 \%$ of cinnamon in the feed increases the activity of microbial enzymes, which improves absorption of nutrients $(29,33-35)$. Better results in carp growth are also found when adding ginger to the feed $(29,36)$.

The common carp from the experimental group with the addition of $1 \%$ cinnamon extract to 
the feed has a better economic efficiency factor of 2.69 , which is lower by $4.61 \%$ compared to the value of this parameter of fish from the control group.

\section{CONCLUSION}

The results showed that cinnamon extract had a positive influence as a feed supplement on the growth of common carp in a recirculation system, its feed conversion ratio and economic efficiency. Experiments on cinnamon as a supplement of carp's pellets should continue at higher concentrations, and to be studied its effect in other species.

\section{REFERENCES}

1. Abdel-Tawwab, M. The use of American ginseng (Panax quinquefolium) in practical diets for Nile tilapia (Oreochromis niloticus): growth performance and challenge with Aeromonas hydrophila. Journal of Applied Aquaculture, 24, pp. 366-376, 2012.

2. Ogundari, K., Demand for quantity versus quality in beef, chicken, and fish consumption in Nigeria. Revista de Economia e Agronegocio, 10-1,pp. 29-50, 2012.

3. Doan, V.H., Hoseinifar, H.S., Dawood, M.A.O., Chitmanat, C., Tayyamath, K. Effects of Cordyceps militaris spent mushroom substrate and Lactobacillus plantarum on mucosal, serum immunology and growth performance of Nile tilapia (Oreochromis niloticus). Fish Shellfish Immunol, 70, pp. 57-94, 2017.

4. Galeotti, M. Some aspects of the application of immunostimulants and a critical review of methods for their evaluation Journal of Applied Ichthyology,14, I3-4, pp. 189-199, 1998.

5. Best, P. Tracking consumer desires: towards total traceability of feed and food. Feed Internation, 23 -2, pp. 4-8, 2002.

6. Costa-Pierce \& Barry, A. Sustainable Ecological Aquaculture Systems: The Need for a New Social Contract for Aquaculture Development Source: Marine Technology Society Journal, 44 - 3, pp. 88-112, 25, 2010.

7. Jayaprakash, V. \& Euphrasia, J. Growth performance of Labeo rohita (Han.) to Livol (IHF-1000), a herbal product. Proceedings of the National Academy of Sciences, 63, pp. 1-10, 1996.

8. Citarasu, T., Ramalingam, K.V., Sekar, J.R., Micheal, B.M., Marian, M.P. Influence of the antibacterial herbs,
Solanum trilobatum, Andrographis paniculata and Psoralea corylifolia on the survival, growth and bacterial load of Penaeus monodon post larvae. Aquac International, 11, pp. 583-595, 2003.

9. Sivaram, V., Babu, M.M., Citarasu, T., Immanuel, G., Murugadass, S., Marian, M.P. Growth and immune response of juvenile greasy groupers (Epinephelus tauvina) fed with herbal antibacterial active principle supplemented diets against Vibrio harveyi infections. Aquaculture, 237, pp. 920, 2004.

10.El-Dakar, A.Y., Shalaby, M.S., Saoud, P.I. Assessing the use of a dietary probiotic/prebiotic as an enhancer of spinefoot rabbitfish Siganus rivulatus survival and growth. Aquaculture Nutrition, 13, 6, pp. 407-412, 2007.

11.Sahu, S. , Das, B., Mishra, K., Pradhan, J., Sarangi, N. Effect of Allium sativum on the immunity and survival of Labeo rohita infected with Aeromonas hydrophila. Journal of Applied Ichthyology, 23, 1, pp. 80-86, 2007.

12.Metwally, M.A.A. Effects of Garlic (Allium sativum) on Some Antioxidant Activities in Tilapia Nilotica (Oreochromis niloticus). World Journal of Fish and Marine Sciences, 1,1, pp. 56-64, 2009.

13.Aly, S.M., Mohamed, M.F. Echinacea purpurea and Allium sativum as immunostimulants in fish culture using Nile tilapia (Oreochromis niloticus L.). Journal of Animal Physiology and Animal Nutrition, 94, 5, pp. 31-39, 2010.

14.Citarasu, T. Herbal Biomedicines: a New Opportunity for Aquaculture Industry, pp. 403-414, 2010.

http://dx.doi.org/10.1007/s10499-0099253-7.

15.Harikrishnan, R., Balasundaram, C.M.S., Heo, S.M. Impact of plant products on innate and adaptive immune system of cultured finfish and shellfish, Aquaculture, 317, pp. 1-15, 2011.

16.Gabor, E., Şara, A., Molnar, F., Benţea, M. The influence of some phytoadditives on growth performances and meat quality in rainbow trout (Oncorhynchus mykiss). Animal Science and Biotechnologies, pp. 44, 2011.

17.Yılmaz, S., Ergün, S., Çelik, E. Effects of herbal supplements on growth performance of sea bass (Dicentrarchus labrax): Change in body composition and some blood 
parameters. Bioscience and Biotechnology, 1, pp. 217-222, 2012.

18.Yılmaz, S., Ergün, S., Soytaş, N. Enhancement of growth performance and pigmentation in red Oreochromis mossambicus associated with dietary intake of astaxanthin, paprika, or capsicum. Aquaculture - Bamidgeh, pp. 7, 2013.

19.Saleh, N., Michael, R., Mohamed, M. Evaluation of garlic and onion powder as phyto-additives in the diet of sea bass (Dicentrarcus labrax). Aquatic Research, 41, pp. 211-217, 2015.

20.Su, L., Yin, J.J., Charles, D., Zhou, K., Moore, J., Yu, L.L.. Total phenolic contents, chelating capacities, and radicalscavenging properties of black peppercorn, nutmeg, rosehip, cinnamon and oregano leaf. Food Chemistry,100, pp. 990-997, 2007.

21.Kwon, K.H., Jeon, K.W., Hwang, S.J., Lee, G.C., So, S.J., Park, A.J., Ko, S.B., Im, H.S. Cinnamon extract suppresses tumor progression by modulating angiogenesis and the effector function of CD8+ T cells. Cancer Letters, 278, pp.174-182, 2009.

22.Gruenwald, J., Freder, J., Armbruester, N. Cinnamon and health, Crit. Rev. Journal of Nutrition and Food Sciences,50, pp. 822834, 2010.

23.Nabavi, F.S., Di Lorenzo, A., Izadi, M., Sobarzo-Sánchez, E., Daglia, M., Nabavi, M.S. Antibacterial effects of cinnamon: from farm to food, cosmetic and pharmaceutical industries. Nutrients, 7, pp. 7729-7748, 2015.

24.Matan, N., Rimkeeree, H., Mawson, J.A., Chompreeda, P., Haruthaithanasan, V., Parker, M. Antimicrobial activity of cinnamon and clove oils under modified atmosphere conditions. International Journal of Food Microbiology, 107, pp. 180-185, 2006.

25.Shan, B., Cai, Y.Z., Brooks, D.J., Corke, H. Antibacterial and antioxidant effects of five spice and herb extracts as natural preservatives of raw pork. Journal of the Science of Food and Agriculture, 89, pp. 1879-1885, 2009.

26.Thomas. J. \& Duethi, P.P. Cinnamon. In: Peter, K.V., editor.Handbook of Herbs and Spices. Woodhead,Cambridge, United Kingdom, 2001.

27.Azima, F. Antioxidant and anti-pletelet aggregation activities of cassia vera (Cinnamomum burmanni Neess ex Blume) bark extract and its potency in preventing atherosclerosis in rabbit. Dissertation, Graduate School, Bogor Agricultural University, pp. 122, 2004.,

28.Hlebowicz, J., Hlebowicz, A., Lindstedt, S., Björgell, O., Höglund, P., Holst, J.J., Darwiche, G., Almér, L.O. Effects of 1 and $3 \mathrm{~g}$ cinnamon on gastric emptying, satiety, and postprandial blood glucose, insulin, glucose-dependent insulinotropic polypeptide, glucagon-like peptide 1, and ghrelin concentrations in healthy subjects. American Journal of Clinical Nutrition, 89, pp. 815-821, 2009.

29.Ahmad, H.M., El-Mesallamy, A.M.D., Samir, F., Zahran, F. Effect of cinnamon (Cinnamomum zeylanicum) on growth performance, feed utilization, whole-body composition, and resistance to Aeromonas hydrophila in nile tilapia. Journal of Applied Aquaculture, 23, pp. 289-298, 2011.

30.Piedecausa, M.A., Mazón, J.M., García García, B., Hernández, D.M. Effects of total replacement of fish oil by vegetable oils in the diets of sharpsnout seabream (Diplodus puntazzo). Aquaculture, 263, pp. 211-219, 2007.

31.Dedi, J., Arief, A.H., Nurhayati, T., Wasjan, Vinasyiam, A. Growth performance and flesh quality of common carp, Cyprinus carpio feeding on the diet supplemented with cinnamon (Cinnamomum burmannii) leaf. Aquaculture, Aquarium, Conservation \& Legislation - International Journal of the Bioflux Society (AACL Bioflux), 9, 5, pp. 937-943, 7, 2016.

32.Xia, S., Ge, X., Liu, B., Xie, J., Miao, L., Ren, M., Zhou, Q., Zhang, W., Jiang, X., Chen, R., Pan, L. Effects of supplemented dietary curcumin on growth and nonspecific immune responses in juvenile Wuchang Bream (Megalobrama amblycephala). Aquaculture - Bamidgeh, 1174, pp. 12, 2015.

33. Setiawati, M., Jusadi, D., Laheng, S., Suprayudi, A.M., Vinasyiam, A. The enhancement of growth performance and feed efficiency of Asian catfish, Pangasianodon hypophthalmus fed on Cinnamomum burmannii leaf powder and extract as nutritional supplementation, Aquacultural Aquarium, Conserv. Legis. Journal Bioflux Society, pp. 9, 2016.

34.Sivagurunathan, A. \& Innocent, X.B. Immunomodulatory effect of dietary cinnamon in growth and haematology of 
STOYANOVA S., et al.

tilapia challenged with Pseudomonas aeruginosa. International Journal of Pharmaceutical and Phytopharmacological, 3, pp. 277-280, 2017.

35.Abdel-Tawwaba, M., Samirb, F., Asmaa, S., El-Nabyb, A., Mohamed, N.M. Antioxidative and immunostimulatory effect of dietary cinnamon nanoparticles on the performance of Nile tilapia, (Oreochromis niloticus L.) and its susceptibility to hypoxia stress and Aeromonas hydrophila infection. Fish and Shellfish Immunology,74,pp. 19-25, 2018.

36.Korni, M.M.F., Khalil, F. Effect of ginger and its nanoparticles on growth performance, cognition capability, immunity and prevention of motile Aeromonas septicaemia in Cyprinus carpio fingerlings. Aquaculture. Nutrition, 23, pp. 1492-1499, 2017. 